\title{
PEMBEBASAN NARAPIDANA DALAM PRESPEKTIF KONSEP ASIMILASI PANDEMI COVID-19
}

\author{
Rizqi Mely Trimiyati \\ Politeknik IImu Pemasyarakatan \\ melylatahzan@gmail.com \\ Depok, Indonesia
}

\begin{abstract}
The policy of the Minister of Law and Human Rights of the Republic of Indonesia Number 10 of 2020 regarding the release and release of prisoners through the process of assimilation and integration in the response to Covid-19 caused many pros and cons. The research method used in this study is a normative juridical approach, namely through the analysis of a legal problem according to the provisions of the applicable laws and regulations. The type of legal material used is primary law, namely related legislation and secondary legal materials in the form of literature that the author reads such as scientific articles and books. The deepening of this research uses descriptive analytical method which has the aim of being able to describe precisely where in this study the object of research is the release of prisoners in the perspective of the concept of assimilation. The purpose of this research is to find out and understand how the release of prisoners from the perspective of the concept of assimilation is viewed from the point of view of punishment. Based on the results of the study, it showed that the assimilation policy given to prisoners during the Covid-19 pandemic was in accordance with the concept of assimilation, namely by fulfilling the requirements and conditions as stipulated in the legislation. The Class IIB Bantul State Detention Center continues to monitor inmates who are undergoing a virtual assimilation program and continues to coordinate with law enforcement officials including the National Police, Attorney General's Office, Courts, and community leaders around the prisoners' residences..
\end{abstract}

Keywords: Assimilation; Covid-19; Inmates

\begin{abstract}
Abstrak
Kebijakan Menteri Hukum dan HAM RI Nomor 10 Tahun 2020 tentang pengeluaran dan pembebasan narapidana melalui proses asimilasi dan integrasi didalam penanggulangan Covid-19 menyebabkan banyak pro dan kontra. Metode penelitian yang digunakan dalam penelitian ini yaitu pendekatan yuridis normative yakni melalui analisis suatu permasalahan hukum menurut ketentuan peraturan perundang-undangan yang berlaku. Jenis bahan hukum yang digunakan merupakan hukum primer yaitu peraturan perundang-undangan yang terkait dan bahan hukum sekunder berupa literature yang penulis baca seperti artikel ilmiah dan buku-buku. Pendalaman penelitian ini menggunakan metode deskriptif analitis yang memiliki tujuan untuk dapat menggambarkan secara tepat dimana dalam penelitian ini yang menjadi objek penelitian yaitu pembebasan narapidana dalam prespektif konsep asimilasi. Tujuan penelitian adalah untuk mengetahui dan memahami bagaimana pembebasan narapidana dalam prespektif konsep asimilasi ditinjau dari sudut pandang pemidanaan. Berdasarkan hasil penelitian menunjukan bahwa Kebijakan asimilasi yang diberikan kepada narapidana pada masa pandemic Covid-19 telah sesuai dengan konsep asimilasi yaitu dengan dipenuhinya perysratan dan ketentuan sebagaimana yang telah diatur dalam perundang-undangan. Rumah Tahanan Negara Kelas IIB Bantul terus melakukan pemantauan kepada narapidana yang sedang menjalani program asimilasi secara virtual serta terus menjalin koordinasi dengan aparat penegak hukum diantaranya POLRI, Kejaksaan, Pengadilan, serta tokoh masyarakat disekitar tempat tinggal narapidana tersebut.
\end{abstract}

Kata Kunci: Asimilasi; Covid-19; Narapidana

Open Access at:http://ojs.uho.ac.id/index.php/PUBLICUHO/index

Journal Publicuho is licensed under a Creative Commons Attribution 4.0 International License. 


\section{Journal Publicuho}

ISSN2621-1351 (online), ISSN 2685-0729 (print)

Volume 4 Number 3 (August - October), (2021) pp. 874-885

Accredited SINTA SK.NOMOR 28/E/KPT/2019

Open Access at:http://ojs.uho.ac.id/index.php/PUBLICUHO/index

DOI: 10.35817/jpu.v4i3.20109

\section{PENDAHULUAN}

Virus Covid- 19 ialah virus yang menimbulkan peradangan respirasi. World Health Organization( World Health Organization) sudah menetapkan virus Covid- 19 selaku pandemi. Penetapan Covid- 19 selaku pandemi global bertepatan pada 12 Maret 2020 oleh Direktur Jenderal World Health Organization, Dokter Tedros Adhanom Ghebreyesus (Nationalgeographic, 2020). Penerbitan Keputuasan Presiden No 11 Tahun 2020 Tentang Penetapan Musibah Non Alam Penyebaran Corona Virus Diase 2019 selaku Musibah Nasional. Dalam menanggulangi serta meninimalisr terpaut penyebaran virus Covid- 19 diambil dengan mempraktikkan program pola hidup sehat, social distancing serta physical distancing kepada warga luas, tidak terhindarkan warga binaan pemasyakatan yang terdapat di dalam Lapas.

Berdasakan dari peraturan Menteri Kesehatan No 9 Tahun 2020 menjadi salah satu dasar yang dijadikan pertimbangan dalam menanggulangi over kapasitas di Lembaga Pemasyarakatan( Lapas) serta Rumah Tahanan Negeri( Rutan) sehingga pemerintah membuat sesuatu kebijakan pembebasan narapidana ditengah pandemi Covid- 19. Dengan terdapatnya kebijakan tersebut menuai polemik, dimana warga hadapi kekhawatiran hendak kenaikan angka kriminalitas ditengah pandemi Covid- 19. Menurut Thomas R Dye (dalam Wayne Parsons, 2005: xi) yang dilkutip dari (Elwan, L.O.M, 2011:15). "public policy is whatever governments choose to do or not to do" kebijakan publik sebagai "apapun pilihan pemerintah untuk melakukan atau tidak melakukan. Dalam upaya mencapai tujuan negara, pemerintah perlu mengambil pilihan tindakan yang dapat berupa melakukan sesuatu atau tidak melakukan sesuatu. Keduanya, menurut definisi Dye, merupakan kebijakan publik karena merupakan upaya mencapai tujuan tertentu dan keduanya memiliki dampak terhadap masyarakat (Supriadin, Alam, \& Elwan, 2020).

Demikian halnya dengan kebiajkan yang sudah dikeluarkan oleh pemerintah terkait dengan pelaksanaan asimilasi tersebut makan dikeluarkannya Peraturan menteri Hukum dan HAM Nomor. 10 Tahun 2020, tentang Ketentuan Pemberian Asimilasi dan Hak Intergrasi Untuk Narapidana dan Anak Dalam Rangka Pencegahan dan Penanggulangan Penyebaran Covid- 19. Keputusan Menteri Hukum dan HAM RI Nomor. M.HH- 19 PK. 01. 04. 04 Tahun 2020 tentang Pengeluaran dan Pembebasan Narapidana dan Anak Melalui Asimilasi dan Integrasi dalam Rangka Pencegahan dan Penanggulangan Penyebaran Covid-19. Surat Edaran Direktur Jenderal Pemasyarakatan No: PAS- 497. PK. 0104, 04 Tahun 2020 Tentang Pengeluaran serta pembebasan Narapidana serta Anak Melalui Asimilasi serta Integrasi. Peraturan Menteri Hukum dan Hak Asasi Manuia Republik Indonesia Nomor 24 Tahun 2021 tentang Perubahan Atas Peraturan Menteri Hukum dan Hak Asasi Manusia Nomor 32 Tahun 2020 Tentang Syarat dan Tata Cara Pemberian Asimilasi, Pembebasan Bersyarat, Cuti 
Menjelang Bebas dan Cuti Bersyarat Bagi Narapidana dan Anak Dalam Rangka Pencegahan Covid-19. Adanya kebijakan pembebasan dan pengeluaran narapidana melalui proses asimilasi dan intergrasi menimbulkan sebuah kontroversi sosial. Sebagian kalangan memberikan penilaian terkait pengambilan kebijakan tersebut menjadi langkah yang tepat untuk dapat mengoptimalkan serta menghormati hukum didalam sistem peradilan pidana. Akan tetapi disisi lainnya tidak sedikit masyarakat yang justru menyayangkan terkait kebijakan yang diberikan dari pemerintah dengan mengkhawatirkan berbagai alasan salah satunya akan memberikan dampak ketenangan sosial dan keamanan dimana narapidana yang diberikan asimilasi dapat bergerak bebas di tengah masyarakat.

Masyarakat menjadi risau atasa dasar prespektif tehadap kebijakan pemerintah terhadap penangulangan penularan Covid-19, masyarakat justru menganggap bahwa narapidana lebih baik serta lebih aman untuk tetap berada di dalam Lembaga pemsyarakatan (Lapas) dan Rumah Tahanan Negara (Rutan) dengan melakukan Phsyical discancing. Kehawatiran dari masyarakat semakin tinggi karena masih adanya anggapan narapidana yang diberikan asimilasi tidak menjamin tidak mengulangi tindak kejahatan yang pernah dilakukannya.

Merupakan hal yang wajar jika terjadinya problematika di tengan masyarakat dengan dikeluarkanya kebijakan pencegahan dan penaggulangan penyebaran covid-19 dengan cara membebaskan narapidana. Karena masyarakat masih beranggapan bahwa narapidana yang sedang menjalani proses asimilasi masih rentan dalam melakukan tindak kejahatan setelah keluar dari Lembaga Pemasyarakatan (Lapas) dan Rumah Tahanan Negara (Rutan). Narapidana yang diberikan hak asimilasi tetap berada dalam pantauan Lembaga Pemasyarakatan (Lapas), Rumah Tahanan Negara (Rutan), Balai Pemasyarakatan (Bapas) serta aparat penegak hukum lainnya, dengan demikian masyarakat dihimbau untuk tidak perlu cemas terkait adanya pembebasan narapidana melalui proses asimilasi.

Narapidana yang diberikan asimilasi telah melalui tahap penilaian perilaku, dimana mereka telah dinilai berkelakuan baikk serta mau mengikuti program pembinaan san tidak melakukan tindak pelanggaran disiplin di Lembaga Pemasyarakatan (Lapas) dan Rumah Tahanan Negara (Rutan). Sebelum narapidana dikembalikan ditengah-tengah masyarakat, petugas Lembaga Pemasyarakatan (Lapas) dan Rumah Tahanan Negara (Rutan) memberikan edukasi serta menyampaikan aturan-aturan kedisiplinan ddan sanksi yang akan diperoleh jika melanggar aturan-aturan tersebut. Selanjutnya hak asimilasi dan integrasi tersebut juga akan dicabut apabila narapidana tersebut terbukti melanggar, mereka harus kembali ke Lembaga Pemasyarakatan (Lapas) atau Rumah Tahanan Negara (Rutan). Narapidana tersebut harus menjalankan sisa pidana serta tambahan pidana yang baru. 


\section{Journal Publicuho}

ISSN2621-1351 (online), ISSN 2685-0729 (print)

Volume 4 Number 3 (August - October), (2021) pp. 874-885

Accredited SINTA SK.NOMOR 28/E/KPT/2019

Open Access at:http://ojs.uho.ac.id/index.php/PUBLICUHO/index DOI: 10.35817/jpu.v4i3.20109

Kemudian narapidana yang terbukti melanggar akan dimasukan kedalam sel pengasingan dan tidak akan diberikan hak remisi sampai waktu tertentu sesuai dengan peraturan yang berlaku.

Berdasarkan data yang diperoleh dari http://smslap.ditjenpas.go.id/ jumlah narapidana di Kanwil Daerah Istimewa Yogyakarta Rumah Tahanan Negara Kelas IIB Bantul dalah sebanyak 155 orang narapidana dengan kapasitas 127 orang narapidana (Direktorat jenderal pemasyarakatan, 2020). Konsisi setelah dilekuarkannya kebijakan yang menimbulan prodan kontra tersebut dari masyakarat, salah satunya dilihat dari sisi aspek keamanannya narapidana yang kembali kepada masyarakat tidak ada jaminan narapidana tersebut tidak mengulangi kembali kejahatannya.

Pelaksanaan asimilasi di Rumah Tahanan Negara Kelas IIB Bantul ini dilatar belakangi adanya wabah Covid-19. Salah satu upaya memberikan asimilasi kepada narapidana untuk meminimalisir terjadinya peluang penyebaran Covid-19 dalam Rumah Tahanan Negara Kelas IIB Bantul. Narapidana yang memperoleh hak asimilasi dan hak inegrasi tetap berada dalam pengawasan negara oleh Balai Pemasyarakatan dan Pembimbing Kemasyarakatan sebagai bentuk pertanggung jawaban dan untuk memberikan program bimbingan dan wajib lapor.

Berdasarkan dari uraian diatas, tujuan penelitian ini untuk mengetahui konsep asimilasi dari prespektif pemidanaan dan bagaimana penerapan peraturan hukum tentang sistem pembinaan terhadap narapidana melalui upaya pemberian hak asimilasi di Rumah Tahanan Negara Kelas IIB Bantul.

\section{METODOLOGI}

Metode penelitian yang digunakan dalam penelitian ini yaitu pendekatan yuridis normative yakni melalui analisis suatu permasalahan hukum menurut ketentuan peraturan perundangundangan yang berlaku. Jenis bahan hukum yang digunakan merupakan hukum primer yaitu peraturan perundang-undangan yang terkait dan bahan hukum sekunder berupa literature yang penulis baca seperti artikel ilmiah dan buku-buku. Pendalaman penelitian ini menggunakan metode deskriptif analitis yang memiliki tujuan untuk dapat menggambarkan secara tepat dimana dalam penelitian ini yang menjadi objek penelitian yaitu pembebasan narapidana dalam prespektif konsep asimilasi. Teknik pengumpulan data dalam penelitian ini dilakukan dengan menggunakan studi pustaka untuk dapat mengumpulkan dan menyusun data-data yang berkaitan dengan penelitian yang akan penulis masalah yang diteliti. Dalam melaksanakan analisis informasi kajian yang berkaitan dengan penelitian yang dicoba oleh penulis, hingga memakai analisis normatif kualitatif, normatif sebab penelitian ini berpangkal dari peraturan- peraturan yang terdapat selaku norma hukum positif dan 
berkaitan dengan permasalahan. Kualitatif sebab seluruh informasi yang didudun dan disajikan secara sistematis berikutnya dianalisis kedalam wujud perkata tidak memakai perhitungan maupun rumusan matematika.

\section{HASIL DAN PEMBAHASAN}

\section{Konsep Asimilasi Dalam Prespektif Pemidanaan}

Dalam Undang-Undang Nomor 12 Tahun 1995 Tentang Pemasyarakatan menyebutkan bahwa setiap narapidana merupakan manusia yang harus dilindungi hak hisupnya sehingga harus diperlakukan secara manusiawi, setiap penjara tidak sesuai dengan UUD 1945 dan Pancasila, pada hakikatnya sistem pemasyarakatan memiliki tujuan untuk dapat diterimanya kembali dimasyarakat dan berperan aktif dalam pembangunan dan bertanggung jawab. Dengan demikian Indonesia membutuhkan suatu sistem yang lebih efektif serta sesuai dengan bangsa Indonesia, tidak selalu dan melakukan penerapan pidana penjara yang justru mempunyai lebih banyak dampak negatif dibandingkan dampak positifnya.

Hal yang utama dalam sistem pemidanaan yaitu diterapkannya suatu sanksi serta pemberian pertimbangan mengenai apa yang seharunya dijadikan sanksi suatu tindak pidana sebagai upaya dalam menegakkan berlakunya norma. Lembaga Pemasyarakatan (Lapas) dan Rumah Tahanan Negara (Rutan) memiliki peran sebagai penerapan hukum dan norma kemasyarakatan yang telah dilanggar oleh masyarat. Dengan melakukan penerapan hukum dan norma diharapkan dapat terjadinya perubahan sifat serta cara pandang, berfikir serta perilaku dari warga binaan pemasyarakatan (Situmeang, 2020).

Teori pemidanaan mempunyai erat kaitannya dengan penafsiran hukum pidana subjektif. Dimana teori ini ialah mencari serta menerangkan tentang dasar dari hak negeri dalam menjatuhkan serta melaksanakan pidana tersebut. Tujuan pemidanaan dengan dinamika pertumbuhan kejahatan yang senantiasa hadapi pertumbuhan di warga, dengan mempunyai pertimbangan target yang hendak dicapai ialah teori retribution (pembalasan), teori deterrence( penjeraan), teori rehabilitasi/ re- sosialisasi serta teori reintegrasi sosial/ restorastive justice.

Teori retribution( pembalasan) ialah salah satu teori pemidanaan dimana dititik beratkan pada pembalasan yang hendak diterima oleh pelakon kejahatan. Perihal ini terjalin sebab, pelakon kejahatan berhak menerima apa yang sudah dikerjakannya. Dimana mata dibalas oleh mata, nyawa dibayar oleh nyawa. Umumnya wujud hukuman yang hendak diterima berbentuk hukuman tubuh ataupun raga. Disini kejahatan dikira selaku sesuatu aksi yang tidak baik, sehingga butuh terdapatnya penjatuhan hukuman dari orang yang melaksanakan kejahatan. Tujuan utama dari teori retribution ini tidak mempunyai 


\section{Journal Publicuho}

ISSN2621-1351 (online), ISSN 2685-0729 (print)

Volume 4 Number 3 (August - October), (2021) pp. 874-885

Accredited SINTA SK.NOMOR 28/E/KPT/2019

Open Access at:http://ojs.uho.ac.id/index.php/PUBLICUHO/index

DOI: 10.35817/jpu.v4i3.20109

tujuan lain tidak hanya pembalasan terhadap pelakon kejahatan tersebut dengan menjatuhkan pidana. Walaupun pemidanaan tidak membagikan khasiat terhadap pelakon kejahatan, maupun hendak membuat pelakon kejahatan jadi lebih kurang baik saat sebelum dipidana. Tetapi, hendak senantiasa dijatuhkan pemidanaan. Disini pemidanaan diarahkan selaku balasan. Tujuan retribution (pembalasan) disebut pula buat memuaskan pihak yang dendam, baik warga sendiri ataupun pihak yg dirugikan ataupun jadi korban kejahatan.

Teori Deterrence (penjeraan) didalam teori ini memahami sistem dimana penjeraan terhadap pelakon kejahatan. Penjatuhan pidana digunakan buat menertipkan warga supaya taat pada peraturan yang sudah diresmikan. Dalam teori deterrence hendak membagikan ataupun menjatuhkan pidana dengan tujuan membetulkan perilaku dari pelakon tindak kejahatan. Tidak hanya itu pula, tujuan dari pemidanaan merupakan menghindari terbentuknya kejahatan dicoba oleh pelakon lagi serta dicoba oleh warga. Tidak hanya itu pula penjatuhan pidana pula hendak membagikan rasa khawatir dalam warga buat melaksanakan kejahatan. Berikutnya didalam teori ini menyangka kalau kejahatan tidak senantiasa bisa dipidana. Tetapi penjatuhan pidana senantiasa mencermati butuh tidaknya penjatuhan pidana. Sebab pada hakekatnya penjatuhan pidana bertujuan buat membetulkan pelakon kejahatan jadi orang yang lebih baik lagi serta tidak hendak mengulangi perbuatan kejahatan lagi.

Teori rehabilitasi/ re- sosialisasi dalam teori ini menitik beratkan pada kesejahteraan narapidana ataupun masyarakat binaan pemasyarakatan serta warga. Dimana dalam teori ini bertujuan buat memperoleh pencapaian dimana memanusiakan manusia. Perihal ini dimaksudkan buat membagikan apa yang jadi hak narapidana ataupun masyarakat binaan pemasyarakatan cocok dengan porsinya, tidak terdapat pengurangan terhadap hak hak tersebut. Sebab dalam teori ini sudah memahami dimana terdapatnya penghormatan HAM. penjara selaku perlengkapan rehabilitation/ resosialization (revisi) memakai model tekanan rendah pada warga serta tekanan besar pada orang, dalam makna kalau fokus atensi lebih diperuntukan kepada orang pelanggar, sebaliknya warga kurang diikutsertakan dalam proses revisi. Diilhami oleh berkembangnya psikologi, psikiatri serta ilmu kesejahteraan sosialPendekatannya masih individualistic. Memakai strategi sosialisasi, pemaksaan nilai- nilai dari luar (officer perspektif) diucap re- sosialisasi.

Teori reintegrasi sosial/ restosrastive justice ialah sesuatu pendekatan yang lebih menitik- beratkan pada keadaan terciptanya keadilan serta penyeimbang buat pelakon tindak pidana dan korbannya sendiri. Mekanisme tata kegiatan serta peradilan pidana yang berfokus pada pemidanaan diganti jadi proses diskusi serta mediasi buat menghasilkan 
konvensi atas penyelesaian kasus pidana yang lebih adil serta balance buat pihak korban serta pelakon. Restorasi meliputi pemulihan jalinan antara pihak korban serta pelakon. Pemulihan jalinan ini dapat didasarkan atas konvensi bersama antara korban serta pelakon. Pihak korban bisa mengantarkan menimpa kerugian yang dideritanya serta pelakon pula diberi peluang buat menebusnya, lewat mekanisme ubah rugi, perdamaian, kerja sosial, ataupun kesepakatan- kesepakatan yang lain. proses pemidanaan konvensional tidak membagikan ruang kepada pihak yang ikut serta, dalam menimpa ini korban serta pelakon buat berpartisipasi aktif dalam penyelesaian permasalahan mereka.

Program asimilasi akan diberikan kepada narapidana tindak pidana umum jika telah memenuhi syarat-syarat tertentu. Karena asimilasi merupakan hak yang harus diperolah warga binaan pemsayarakatan. Setiap warga binaan pemasyarakatan yang menjalani hukuman di dalam Lembaga Pemasyarakatan (Lapas) dan Rumah Tahanan Negara (Rutan) teteap mempunyai hak asasi masnuia yang diakui secara universal (Violina \& Wibowo, 2020).

Dilihat dari Undang-undang pemasyarakatan setiap narapidana memiliki kesempatan untuk memperoleh asimilasi. Pemberian asimilasi narapidana melalui asimilasi dan hak integrasi tidak mencakup semua kasus tindak pidana. Terdapat mengecualian terhadap kausus tertentu yang telah diatur dalam Permenkumham No. 10 Tahun 2020 sebagai kebijakan penanggulangan Covid-19. Terdapat pada pasal 8 , narapidana yang tidak termasuk untuk mendapatkan asimilasi dan hak integrasi yaitu narapidana yang melakukan tindak pidana atau penyalah gunaan obat terlarang diantaranya narkotika, psikotropika dll .

Asimilasi merupakan proses pembinaan narapidana yang dilaksanakan dengan membaurkan narapidana dengan kehidupan masyarakat. Hak remisi untuk narapidana sepenuhnya diberikan oleh presiden. Seperti hak untuk pembebasan bersyarat harus adanya remisi. Selain itu Cuti Bersyarat (CB), Cuti Mengunjungi Keluarga (CMB), Pembebasan Bersyarat (PB). Ilmu tentang remisi harus dipahami. Sesuai dengan peraturan yang ada, hak narapidana harus diberikan sesuai dengan Permenkumham Nomor 3 Tahun 2018

Adapun tahapan pembinaan narapidana dibagi menjadi berikut:

a) Tahap awal

Pembinaan tahap awal diberikan kepada yang bersangkutan berstatus Narapidana dimulai dari $0 \mathrm{~s} / \mathrm{d} 1 / 2$ masa pidana. Dalam sesi ini dicoba masa pengamatan, pengenalan serta riset area sangat lama 1( satu) bulan, selanjunya perencanaan program pembinaan karakter serta kemandirian, setelah itu penerapan program pembinaan karakter serta kemandirian. Dalam tiap melakukan program terdapat penilaiannya. 


\section{Journal Publicuho}

ISSN2621-1351 (online), ISSN 2685-0729 (print)

Volume 4 Number 3 (August - October), (2021) pp. 874-885

Accredited SINTA SK.NOMOR 28/E/KPT/2019

b) Tahap lanjutan kedua

Pembinaan tahap lanjutan kedua dimulai dari $1 / 2 \mathrm{~s} / \mathrm{d} 2 / 3$ masa pidana. Dalam sesi ini ialah sesi perencanaan serta pelaksanakannya program asimilasi. Dimana narapidana yang sudah penuhi persyaratan bisa mengajukan asimilasi.

c) Tahap akhir

Pada tahap pembinaan akhir dimulai dari sejak $2 / 3 \mathrm{~s} / \mathrm{d}$ berakhirnya masa pidana, dimana dalam tahap akhir ini dilakukan perencanaan program integrasi, pelaksanaan program integrasi serta pengakhiran pelaksanaan pembinaan akhirr.

Menurut Peraturan Menteri Hukum dan Hak Asasi Manusia Republik Indonesia Nomor 24 Tahun 2021 sebagai mana telah disebutkan dalam pasal 45 yaitu narapidana yang telah menjalani 1/2 masa pidananya dapat mengajukan asimilasi dan narapidana yang telah menjalani 2/3 masa pidananya dapat mengajukan hak integrasi sampai dengan tanggal 31 Desember 2021 (Permenkes 65 tahun, 2015). Tujuan dari asimilasi yaitu mempersiapkan narapidana untuk kembali menjalani kehidupan bermasyarat dengan baik.

Narapidana yang telah memenuhi syarat-syarat asimilasi, maka dapat diberikan haknya tersebut, dimana pemberian asimilasi atas rekomendasi dari Balai Pemasyarakatan (Bapas) yang disetujui oleh Kepala Lembaga Pemasyarakatan (Lapas) atau Kepala Rumah Tahanan Negara (Rutan). Pembinaan yang membaurkan narapidana dengan kehidupan lingkungan masyarakat dengan menggunakan prinsip resosialisasi dalam Sistem Pemasyarakatan, dimana melihat adanya prubahan sifat dari narapidana dalam resosialisasi tersebut (Yuliandhari et al., n.d.). Perubahan sikap tersebut diperoleh dari sistempembinaan yang baik dengan mengutamakan pendekatan yang lebih manusiawi (Appludnopsanji \& Disemadi, 2020). Dengan menggunakan pendekatan-pendekatan akan lebih efektif untuk melakukan pencegahan dan sebagai upaya penanggulangan terjadinya pengulangan tindak pidana yaitu salah satunya menciptakan lingkungan pembinaan yang perupakan refleksi dari lingkungan masyarakat.

Terdapat perbedaan yang cukup mendasar terhadap pelaksanaan program asimilasi yang berdasarkan Permenkumkam Nomor 24 Tahun 2021 dimana asimilasi dilaksanakan di rumah, hal tersebut sejalan dengan kebijakan pemerintah untuk melaksanakan sosial distancing sebagai dalah satu upaya pencegahan Covid-19. Pelaksanaan program asimilasi tersebut terut serta diawasi oleh Pembimbing Kemasyarakatan yang memiliki tugas utama pengawas dan pembimbingan (Hidayat, 2020).

Terdapatnya kebijakan tersebut mempunyai pengaruh terhadap tujuan akhir dari program asimilasi ialah tiap narapidana bisa berbaur kembali dengan warga dan mempunyai keahlian. Tidak selaras dengan pemidanaan yang memiliki guna selaku upaya penangkalan 
terbentuknya tindak pidana dengan melaksanakan penegakan terhadap norma hukum buat menghasilkan pengayoman warga, tidak hanya itu pula pemidanaan mempunyai tujuan penyelesaian konflik yang bersumber dari tindak pidana setelah itu diadakannya pemulihan terhadap penyeimbang warga. Setelah itu selaku wujud reintegrasi narapdana kedalam warga lewat aktivitas pembinaan sehingga diharapkan jadi orang yang baik serta bermanfaat dalam warga kembali. Memandang dari guna dan tujuan pemidanaan tersebut, hingga sepatutnya tidak terdapat lagi mengulang melaksanakan tindak pidana. Hendak namun dengan kebijakan ini mendatangkan tindak pidana baru serta tidak cocok dengan tujuan pemidanaan yang terdapat (Tantaru et al., 2021).

Kebijakan pencegahan dan mitigimasi Covid-19 berfokus pada pembatasan kegiatan diluar ruang, dimana memberikan dampak yang sangat besar terhadap kesetabilan ekonimi masyarakat luas, adapun akibat yang ditimbulkan yaitu tidak sedikit diantara mereka yang melakukan tindak kriminalitas untuk memenuhi kebutuhan ekonominya. Selanjutnya kebijakan pencegahan dan mitigimasi Covid-19 pemerintah membebaskan kurang lebih dari 57.000 narapidana (Wib \& Ika, 2020). Narapidana yang mendapatkan hak asimilasi tersebut pada saat keluar dari penjara akan dihadapkan dengan kenyataan kesulitan untuk mencari pekerjaan dan penghasilan yang tetap kerna adanya kebijakan migtimasi Covid-19. Tidak menuntut kemungkinan mereka akan mengambil jalan pintas lagi dengan melakukan tindak criminal untuk dapat memenuhi kebutuhan hidupnya.

Sejauh ini, tercatat 106 narapidana yang tersebat di 19 Polda yang menjalani asimilasi telah melakukan tindak kriminalitas kembali (Polri Catat 106 Napi Asimilasi Covid-19 Kembali Lakukan Tindak Pidana, n.d.). Terjadinya tindak kriminalitas yang dilakukan oleh narapidana asimilasi covid-19 ini, penekanan secara kuat difokuskan pada aspek penegakan hukuman secara lebih tegas dan serius. Didasarkan dari hal tersebut, maka pemberian kebijakan asimilasi pada masa pendemi Covid-19 kurang tepat, maksudnya secara konsep bahwa asimilasi telah sesuai dengan Undang-Undang Nomor 12 Tahun 1995 tentang Pemasyarakatan, tetapi demikian didalam penerapannya di lapangan hadapi bermacam hambatan semacam halnya jumlah petugas yang masih kurang, partisipasi dari narapidana dalam program pembinaan masih lumayan rendah, fasilitas serta prasarana yang terbatas, sedikitnya anggaran dalam pembiayaan aktivitas pembinaan dan terdapatnya sitgma dari masyarat kepada narapidana yang masih sangat kurang baik (Frank van Steenbergen \& Tuinhof, 2009). Hal tersebut dapat diibaratkan jika kita akan mengalikasikan pasar, maka pedagang yang berada didalamnya tidak cukup hanya diperintahkan untuk keluar begitu saja, akan tetapi pedang-pedagang tersebut harus diberikan fasilitas untuk dapat melakukan kegiatan berdagang kembali dengan lancar dan dapat berjalan dengan baik. Demikian juga halnya pemberian asimilasi agar dapat berjalan dengan lancar dan sesuai 


\section{Journal Publicuho}

ISSN2621-1351 (online), ISSN 2685-0729 (print)

Volume 4 Number 3 (August - October), (2021) pp. 874-885

Accredited SINTA SK.NOMOR 28/E/KPT/2019

Open Access at:http://ojs.uho.ac.id/index.php/PUBLICUHO/index

DOI: 10.35817/jpu.v4i3.20109

dengan tujuannya, narapidana yang mendapat asimilasi dan tidak melakukan tindak kriminalitas kembali. Jika terjadi tindak kirminalitas dari narapidana yang sedang melakukan asimilasi maka program asimilasi tersebut tidak ada manfaatnya.

\section{Kebijakan Asimilasi Pada Masa Pandemi Covid-19 Di Rumah Tahanan Negara Kelas IIB Bantul}

Menurut Jones (1991) dalam La Ode Muhammad Elwan, (2011: 18) menjelaskan bahwa Implementasi kebijakan mudah dimengerti secara teoritik dan konseptual, namun tidak senantiasa demikian dalam bentuknya yang kongkrit, karena pelaksanaannya secara nyata bukanlah sesuatu yang mudah (Supriadin et al., 2020). Kebijakan itu sendii sebenarnya bertujuan untuk menemukan formula penyelesaian masalah publik yang sifatnya krusial dibutuhkan oleh masyarakat dalam bentuk pelayaan publik. Menurut Dwiyanto (2006:56) yang dikutip dari La Ode Muhammad Elwan. (2019) bahwa pemberian pelayanan publik oleh aparatur pemerintah kepada masyarakat (publik) merupakan perwujudan dan fungsi aparatur negara sebagai pelayan masyarakat (abdi), disamping sebagai abdi negara. Dalam konteks ini masyarakatlah sebagai aktor utama (pelaku) pembangunan, sedangkan pemerintah berkewajiban untuk mengarahkan, membimbing serta menciptakan suasana yang menunjang kegiatan-kegiatan dari masyarakat tersebut. Pada kondisi ini aparatur negara dituntut untuk lebih mampu memperbaiki kinerjanya (pelayanan prima) dan diharapkan lebih mampu merumuskan konsep atau menciptakan iklim yang kondusif, sehingga sumber daya pembangunan dapat menjadi pendorong percepatan terwujudnya masyarakat yang mandiri dan sejahtera. Pelayanan yang telah menunjuk kepada aturan formal dianggap telah memenuhi sendi-sendi pelayanan yang baik dan aparat pelayanan dianggap telah konsisten dalam menerapkan aturan hukum pelayanan. (Muhammad Elwan, 2019)

Ditengah pandemi Covid-19, pemerintah mengeluarkan kebijakan untuk melakukan penanggulangan terhadap persebaran Covid-19 diantaranya pembatasanan sosial berskala besar, melihat kondisi tersebut, over kapasitas yang terjadi di Lembaga Pemasyarakatan (Lapas) dan Rumah Tahanan Negara (Rutan). Dengan kondisi yang demikian pemerintah mengeluarkan Surat Edaran No: PAS- 14. HH. 01.04 Tahun 2021 Tentang Penindakan Covi- 19 Pada Unit Pelaksana Teknis Pemsyarakatan Dalam Pemberlakukan Pembatasan Kegiatan Masyarakat (PPKM) Darurat Di Daerah Jawa- Bali.

Kebijakan yang diambil oleh Kementerian Hukum dan HAM tersebut memiliki tujuan sebagai upaya untuk mecegah serta menanggulangi penyebaran covid-19 di Lembaga Pemasyarakatan dan Rumah Tahanan Negara. Menindak lanjuti kebijakan dari perpanjangan pemberian asimilasi ditengah pandemi Covid-19 di Rumah Tahanan Negara Bantul melakukan peraturan pemberian hak asimilasi dan integrasi kepada narapidana yang telah memenuhi persyaratan dapat mengajukan serta melaksanakan asimilasi. Adapaun 
pelaksanaan asimilasi tersebut dilakukan di rumah narapidana masing-masing. Kebijakan ini berlaku per tanggal 31 desember 2021.

Pemberian asimilasi tersebut tidak berlaku kepada narapidana yang termasuk dalam kategori tindak pidana yang ada di dalam PP 99 diantaranya tindak pidana korupso, terorisme, tindak pidana terhadap kemanan negara, tindak kejahatan transnasional terorganisasi, narapidana warga negara asing serta kejahatan HAM berat. Dalam pelaksanaannya terdiri dari pemenuhan syarat administrative dan syarat subtantif. Subtantif diantaranya yaitu menunjukan kesadaran dan perubahan perilaku dan tidak akan mengulangi kembali perbuatannya, telah memberi serta menunjukan suatu moral yang positif dan berbudi pekerti yang bagus selama menjalani hukuman di dalam Rumah Tahanan Negara Kelas IIB Bantul, serta mau menaati peraturan selama menjalankan pembinaan. Adapaun syarat administrative berupa dokumen dokumen yang harus dipenihi oleh narapidana yang bersangkutan untuk dapat memperoleh hak asimilasi tersebut.

Rumah Tahanan Negara Kelas IIB Bantul terus melakukan pemantauan kepada narapidana yang sedang menjalani program asimilasi secara virtual serta terus menjalin koordinasi dengan aparat penegak hukum diantaranya POLRI, Kejaksaan, Pengadilan, serta tokoh masyarakat disekitar tempat tinggal narapidana tersebut. Hal tersebut dilakukan sebagai upaya yang perlu dilakukan untuk memastikan narapidana tetap berada didalam rumah serta dapat menjalankan segala konsekuensi dari program tersebut. Selain itu juga, pemantauan yang dilakukan untuk memastikan narapidana tetap berkelakuan baik ketika menjalani proses asimilasi dirumah, mengingat jika melakukan pelanggaran atau tindak kriminalitas maka narapidana tersebut harus kembali ke Rumah Tahana Negara (Rutan) untuk menjalani sisah masa pidananya dan menjalankan pidana yang baru.

Berbagai upaya dilakukan di Rumah Tahanan Negara Kelas IIB Batul untuk mencegah penyebaran Covid-19 diantaranya menyiapkan ruang isolasi jika ada warga binaan pemasyarakatan yang terdeteksi Orang Tanpa Gejala (OTG), Orang Dalam Pemantauan (ODP) dan Pasien Dalam Pengawasan (PDP), selanjutnya untuk kunjungan ditiadakan digantikan dengan Video Call, menyediakan bilik sterilisasi, tempat cuci tangan, pengecekan suhu, melakukan kerjasama dengan Dinas Kesehatan, melakukan penyemprotan disinfektan, menyediakan sarana deteksi awal, melakukan penghentian sementara terkait kegiatan yang menimbulkan kerumunan, penundaan penerimaan tahanan baru, melakukan kerja sama dengan aparat penegak hukum. 


\section{Journal Publicuho}

ISSN2621-1351 (online), ISSN 2685-0729 (print)

Volume 4 Number 3 (August - October), (2021) pp. 874-885

Accredited SINTA SK.NOMOR 28/E/KPT/2019

Open Access at:http://ojs.uho.ac.id/index.php/PUBLICUHO/index

DOI: 10.35817/jpu.v4i3.20109

\section{KESIMPULAN}

Kebijakan asimilasi yang diberikan kepada narapidana di Rumah Tahanan Kelas IIB Bantul pada masa pandemic Covid-19 telah sesuai dengan konsep asimilasi yaitu dengan dipenuhinya persyaratan dan ketentuan sebagaimana yang telah diatur dalam perundangundangan. Adapun pelaksanaan pemberian asimilasi tidak mengalami suatu habatan serta dapat berjalan dengan lancar. Rumah Tahanan Negara Kelas IIB Bantul terus melakukan pemantauan kepada narapidana yang sedang menjalani program asimilasi secara virtual serta terus menjalin koordinasi dengan aparat penegak hukum diantaranya POLRI, Kejaksaan, Pengadilan, serta tokoh masyarakat disekitar tempat tinggal narapidana tersebut.

\section{REFERENSI}

Appludnopsanji, A., \& Disemadi, H. S. (2020). Problematika Kebijakan Pembebasan Narapidana sebagai Upaya Penanggulangan COVID-19 di Indonesia. Jurnal Wawasan Yuridika, 4(2), 131. https://doi.org/10.25072/jwy.v4i2.369

Direktorat jenderal pemasyarakatan. (2020). Laporan UPT. http://smslap.ditjenpas.go.id

Elwan, M., \& Ode, L. (2019). Problem Birokrasi dalam Meningkatan Pelayanan Publik pada Sekretariat Daerah Kabupaten Muna. Journal Publicuho, 2(2), 31-42.

Frank van Steenbergen, \& Tuinhof, A. (2009). 済無No Title No Title No Title. Angewandte Chemie International Edition, 6(11), 951-952.

Hidayat, R. H. (2020). Langkah-Langkah Strategis Untuk Mencegah Pandemi Covid-19 Di Lembaga Pemassyarakatan Indonesia. Jurnal Pendidikan Kesehatan, 9(1), 43-55.

Nationalgeographic. (2020). WHO Tetapkan COVID-19 Sebagai Pandemi Global, Apa Maksudnya? - National Geographic. In Nationalgeographic.

https://nationalgeographic.grid.id/read/132059249/who-tetapkan-covid-19-sebagaipandemi-global-apa-maksudnya

Permenkes 65 tahun. (2015). Berita Negara. Menteri Kesehatan Republik Indonesia Peraturan Menteri Kesehatan Republik Indonesia, Nomor 65 (879), 2004-2006.

Polri Catat 106 Napi Asimilasi Covid-19 Kembali Lakukan Tindak Pidana. (n.d.).

Situmeang, S. M. T. (2020). Pembebasan Narapidana Dalam Perspektif Konsep Asimilasi Di Masa Pandemi Covid 19. Litigasi, 21 (2), 220-237.

Supriadin, R., Alam, S., \& Elwan, L. O. M. (2020). IMPLEMENTASI PERATURAN WALIKOTA KENDARI NOMOR 13 TAHUN 2008 TENTANG PENATAAN PEDAGANG KAKI LIMA DI KOTA KENDARI. Journal Publicuho. https://doi.org/10.35817/jpu.v3i1.11506

Tantaru, F., Toule, E. R. M., \& Ubwarin, E. (2021). Kajian Sosio-Yuridis Pembebasan Bersyarat dan Pemberian Asimilasi Bagi Narapidana pada Masa Pandemi Covid-19 Ditinjau Dari Perspektif Tujuan Pemidanaan. Sanisa: Jurnal Kreativitas Mahasiswa Hukum, 1 (1), 1.

Violina, Y., \& Wibowo, P. (2020). Pemberian Program Asimilasi Dan Integrasi Bagi Narapidana Dan Anak Sebagai Langkah Pencegahan Penyebaran Virus Corona. Nusantara: Jurnal Ilmu Pengetahuan Sosial, 7(2), 408-420.

Wib, A., \& Ika, O. (2020). Cegah Penyebaran Covid-19 (Issue April).

Yuliandhari, S. A., Hukum, F., Pembangunan, U., Veteran, N., Labu, P., \& Selatan, J. (n.d.). EFEKTIVITAS PEMBINAAN LEMBAGA PEMASYARAKATAN GUNA MENCEGAH TERJADINYA RESIDIVIS ASIMILASI DI ERA PANDEMI COVID-19.978-979. 